\title{
Evaluation of educational websites to support Primary and High school in Portugal
}

\author{
Ana M. Santos ${ }^{i}$ \\ Univ Portucalense, Portucalense \\ Institute for Legal Research - IJP, \\ Oporto, Portugal \\ +351225572000 \\ ana.santos@upt.pt
}

\begin{abstract}
This study aims to evaluate the quality of educational websites focused on learning support of two degrees of education, Primary School and the High school. To develop this analysis was used a Model of Evaluation of the Quality of Educational Websites (EQEWS). This Model divided into Functional Aspects, with five criteria: Authority, Update, Usability, Accessibility and Communication; and in Technical and Aesthetic Aspects, with five criteria: Graphic Design and Multimedia Quality, Content, Navigation, Speed of Access and Interaction. This model of evaluation applied to 57 websites, according to the Likert scale of 0 to 4 . The data subjected to statistical analysis with the support of computer calculation tool SPSS, version 23. Through this exploratory study concluded that educational websites that had better ranking with higher average values were affected by High School Websites. We conclude that the creators of these resources aren't conscience of the importance to assess their resources from heuristics evaluation, even before putting them on the Internet. It was noted the failure of the functional and technical requirements for who conceives, publishes and maintains their content online, often for lack of knowledge in handling these new technologies.
\end{abstract}

\section{Categories and Subject Descriptors}

Social and professional topics $\rightarrow$ computing education $\rightarrow$ Information science education $\rightarrow$ Computing literacy

\section{General Terms}

Documentation

\section{Keywords}

Evaluation of educational websites / Primary School / High School / Teaching / Evaluation criteria / Education

\section{INTRODUCTION}

People use the Internet in all areas of knowledge, not only looking for information but also to communicate with each other. As such, the Internet is considered the largest and most vast repository in the world, where different types and quality of information [4]. Currently, the Internet allows sharp democratic access to information is adopting new models of access, new query interfaces facilitating users haven't any experienced of needs in information retrieval and handling of websites. This instrument has become an increasingly useful tool for all types of organizations [2]. Now the electronic educational resources are becoming more present in the teaching-learning process. The development of the Internet and the evolution of information and communication technology tools have transformed the educational scenario, through the emergence of new spaces, where present in its new features, with different methodologies and resources. The educational community needs to establish a set of clear and relevant criteria, related to the assessment, which makes it possible to determine the quality of online resources to support learning and ensure a better quality of the teaching and learning process.

The consumption of large content and accessibility to information continues to grow on a large scale. With this in perspective, and knowing that young people need to select information and taking into account a significant amount of information it offers on the Internet, it's important to carry out a study that allows creating evaluation instruments. Thus, this study aims to evaluate to help students' choose their quality information and evaluating this kind of information instrumental.

There is no precise definition of an educational internet site [17]. Can be a site of an educational institution, how can it be a place without any learning function. However, the most proper definition in this study used by Area Moreira [3], which refer that an educational website such as spaces or pages that located on the Internet and they offer in addition to information, also educational resources or even educational learning support materials according to the age groups under study.

Most of these educational websites are built by teachers or by schools. Underlining also the definition of López Carreño [9] educational resource where the educational portals provide users with data and information in the form of links, documents, resources, software, etc. are essential for the development of instruments for learning, not only used by students, but also by teachers and parents. Hinrichs and Carpendale [7] refer "usage habits of young learners have to be taken into account when developing such a website. Users' age is necessary for gestures interaction because children and adults intuitively choose different gestures". So help authors' create this kind of e-contents with some quality.

This study follows on the quality evaluation of educational websites and which serve to support the learning disciplines for the Primary and High School in Portugal. 


\section{OBJECTIVE}

The purpose of this study was to investigate the quality of online resources for primary education concerning Secondary Education in the Portuguese territory, i.e. in which teaching cycles there is greater caution in the evaluation criteria. If you comply with the assessment criteria established and used in the Evaluation of the Quality of Educational Websites (Model of EQEWS) [16] adapted by reading several authors that will be mention in the methodology.

\section{METHOD}

The method characterized by lifting all educational websites exists on the Internet. The research had the help of various search engines (Google, sapo, aeiou), facilitating the listing of most of the educational resources in line and directed to support primary and secondary education. The survey conducted to the third page on the Internet and all URL addresses were collected a Data Description File, adapted by Codina (2000). Another source of map and retrieve the URL's based on the observation of these resources that possessed the list of other sites.

In the phase of the survey of all websites, we counted about three hundred and fifty locations. However, for the sample was smaller, were drawn-limiting requirements: be suitable for young people between six and ten and fifteen and seventeen years; include free websites; include only Portuguese online resources (excluding Brazilian origin web sites) and delete all resources that were Blogs.

The sites were selected and evaluated in a total of fifty-seven, after all, these sources of selection.

Study with an exploratory purpose of developing a quantitative and qualitative approach, by considering the interpretation of statistical data. The vision of the observer-evaluator on an evaluation of websites, how to support the theoreticalmethodological assumptions general by Olsina [13]. Also Jiménez Piano and Ortiz-Repiso [8], Codina [6] and Nielsen [12] (the latter, internationally known as the "father of usability," which has developed several researchers in the area of assessment of the usability of Websites). Other authors' was more focused on the evaluation of educational websites, such as Marquès Graells [11], Carvalho [5], Pinto Molina and Gómez-Camareiro [14] e López Carreño [9]. Later, and with the need to expand and diversify the search universe in a new assessment also was used as a basis, the theoretical assumptions from Olsina et al. [13], Carvalho [5], Codina [6], Pinto Molina [15], adapted by Santos [16].

To carry out this evaluation was necessary to know and identify educational websites available on the Internet that were directed to support the learnings from the Primary School of basic education and High School. We found 57 sites that satisfied the evaluation requirements, which was applied the Model of EQEWS, observed and scored according to a Likert scale of 0 to 4 in different assessment criteria.

The selection of this group of educational websites was a very lengthy and complicated process, given the nature of the selection criteria and the requirements intended. In the first place, and because there's in all cases a clear indication of the target audience of the website, it was necessary to analyze carefully each of the sites to ensure that would be suitable and the interest of students' in the Primary and High School.

Besides, we considered that without resources contain information with school standards, can find websites with educational interest, providing learning and, consequently, programmatic e-content targeted to the Primary School of mandatory education and High School.

Educational sites analyzed are mostly created by teachers. However, there are some institutional, but both had as objective to support the students in learning materials. These facilities produce mainly through the contribution of Professor in its various tasks, such as content producer, designer, technologist, promoter of the information, as well as instructive strategy. However, one difficulty with which many teachers face is the fact that they didn't dominate all these areas. That's why this study, whether these online resources have achieved a qualification Sufficient, Good and Very Good (Excellent) on a Likert scale to the evaluation criteria.

Ten rules form an essential part of the set of criteria for the assessment of digital resources, and the control of these measures can be considered the strongest tool for resource managers evaluated since it involves virtually all the others. Therefore, the study of websites directed to these criteria (Authority, Update, Usability, Communication, Graphic Design and Multimedia Quality, Content, Navigation, Accessibility, Speed of Access and Interaction).

After all these limitations and delimitations we can ascertain a considerable number of educational websites to support learning and fulfill our requirements previously established featuring the sample of this study (see Annex 1).

In this section, we describe the sample we have counted upon to perform this study. In Figure 1 shows the frequency and percentage of websites by the level of education, where we find that the majority of sites is for the High school $(n=37 ; 64.9 \%)$, the remaining Primary School $(n=20 ; 35.1 \%)$. 


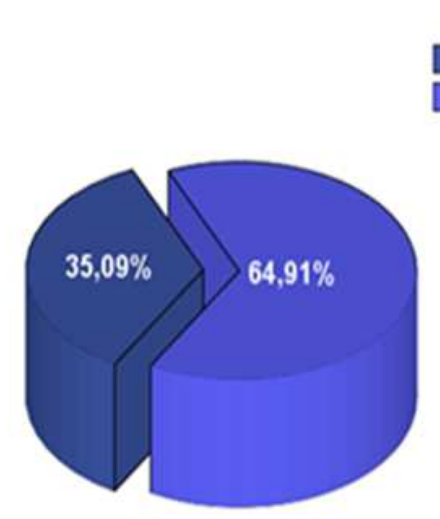

Figure 1. Percentage of websites by level of education

The total number of the study presented here will be of 57 educational sites, 20 for Primary School and 37 for the High School applying the quality assessment instrument (EQEWS model).

Before the application of EQEWS model a pre-test to prove that the model did not contain any failure. Later the valuation criteria were set Likert scale to adapt to the study concerned. As there was nothing to modify continued with its implementation. The data collected between 26 of November and 1 of December 2015.

\section{Vertical analysis results}

For the proper presentation of the data, it was fallen back upon the use of tables with the respective statistical information that will precede of the individual analysis. It obtained the analysis of the data by descriptive statistics and inferential used the software SPSS 23.0 (Statistical Package for the Social Sciences).

Taking into account the fulfillment of the necessary criteria for the realization of parametric hypothesis testing it appears that the sample doesn't follow a normal distribution in the variables under study, for this reason, we used this test. The nonparametric test of Mann-Withney (see Table 4) was used to verify the existence of significant differences in the aspects of a study, for a type of teaching degree, the one that refers the Ranches web.

The Mann-Whitney Test is the non-parametric test suitable to compare the distribution functions of one variable at least ordinal in two independent samples [10].

Trough the results collected in the program SPSS, tables and graphs built in Excel, with the values of cumulative averages for criteria, tables with maximum and minimum values for Functional and Technical Aesthetics Aspects and standards. The results observed through the descriptive analysis.

So, the data collected in two phases: the first moment occurred after direct observation, i.e. the collection of EQEWS model evaluation and recorded all submissions and comments that if considered relevant.

In Table 1 is presented the average, standard deviation, minimum, and maximum of the Functional Aspects and the Technical Aesthetic Aspects and their criteria. Where we can observe that the Technical Aesthetic Aspects present a higher rating (average $=$ $2.21 ; \mathrm{dp}=0.23$ ) in respect to the Functional Aspects (average $=$ $1.75 ; \mathrm{dp}=0.34$ ). Concerning the criteria of Functional Aspects of Usability the features top score (mean $=2.02 ; \mathrm{dp}=0.53$ ), and the Accessibility to that offers worse rating (average $=1.16$; $\mathrm{dp}=$ 0.36). About the Criteria of Technical Aesthetic Aspects the Speed of Access is the one that reveals the highest score (mean = 3.40; dp = 0.60), the Graphic Design and Multimedia Quality which presents lower rating (average $=1.50 ; \mathrm{dp}=0.52$ ).

Table 1. Mean, standard deviation, minimum and maximum of the factors under study

\begin{tabular}{|l|c|c|c|c|}
\hline & Mean & dp & Mimum & Maximum \\
\hline Functional Aspects & 1,75 &, 34 & 1,17 & 2,66 \\
\hline Funchnical and Aesthetic Aspects & 2,21 &, 23 & 1,78 & 2,79 \\
\hline Authority & & & & \\
\hline Update & 1,78 &, 45 &, 83 & 3,00 \\
\hline Usability & 1,97 &, 67 & 1,00 & 3,67 \\
\hline Accessibility & 2,02 &, 53 & 1,00 & 3,00 \\
\hline Communication & 1,16 &, 36 &, 80 & 2,30 \\
\hline Technical and Aesthetic Aspects & 1,81 &, 56 & 1,00 & 3,00 \\
\hline Graphic design and Multmedia quality & 1,50 &, 52 &, 67 & 3,00 \\
\hline Content & 2,56 &, 22 & 2,20 & 3,00 \\
\hline Navigation & 1,81 &, 43 &, 86 & 2,57 \\
\hline Speed Access & 3,40 &, 60 & 2,00 & 4,00 \\
\hline Interaction & 1,79 &, 53 & 1,00 & 2,83 \\
\hline 0=Not Applicable / I=Bad / $=$ Sufficient / 3=Good/4=Very Good & \\
\hline
\end{tabular}

Taking into consideration the evaluation score $(0=\mathrm{N} / \mathrm{A}=\mathrm{Bad} / 2$ $=$ Sufficient $/ 3=$ Good $/ 4=$ Very Good) and as we can see through the extreme quartiles and diagram (Figure 2). The median of the Technical Aesthetic Aspects (median = 1.73) proves to be distinctly higher than the average of the Functional Aspects $($ median $=2.24)$. 


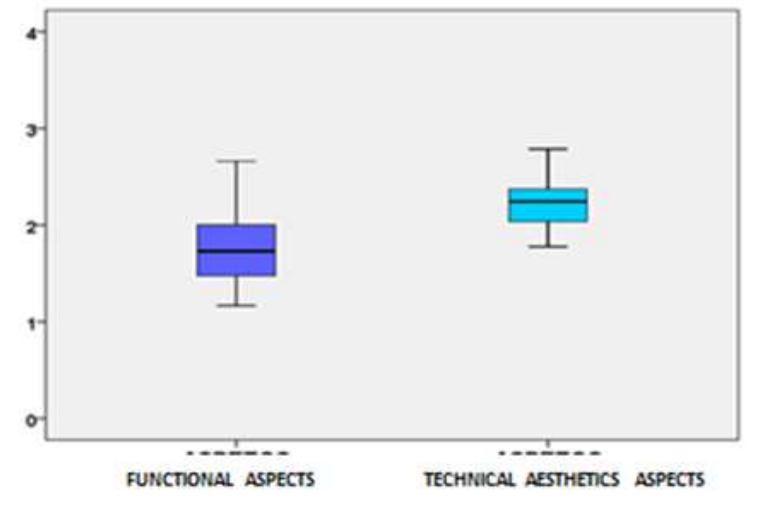

Figure 2 - Extreme diagram and quartiles of Functional and Technical Aesthetic Aspects

Considering the evaluation score $(0=\mathrm{N} / \mathrm{A}=\mathrm{Bad} / 2=$ Sufficient $/ 3$ $=\operatorname{Good} / 4=$ Very Good) we can observe through the extreme quartiles and diagram (Figure 3) the medians of the Functional Aspects (Figure 4) and the Technical Aesthetic Aspects of the medium. We can see in Figure 3 that all most sites the Update had average values out. In the same way, he/she happened with the criterion Accessibility, obtaining ranches web educational with average values above the classification in the category of Sufficient.

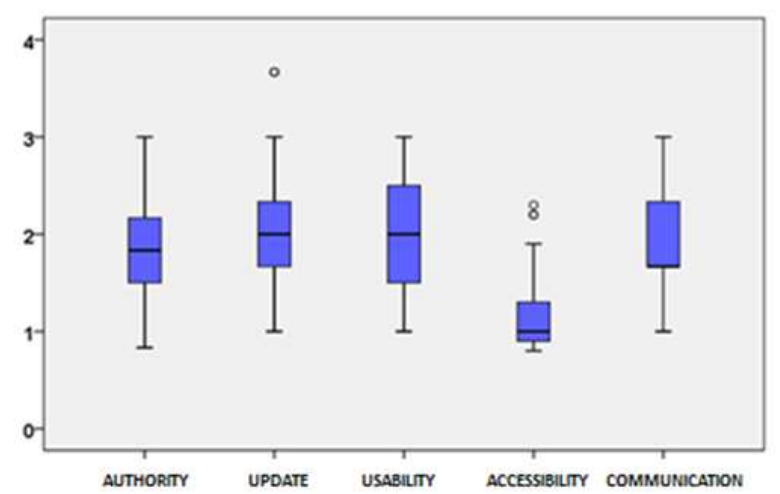

Figure 3. Extreme diagram and quartiles of Functional Aspects

Observing Figure 4 we see that the mean values obtained Content criterion (outliners), i.e. some websites reached achieve benefits of classified in the category of Good.

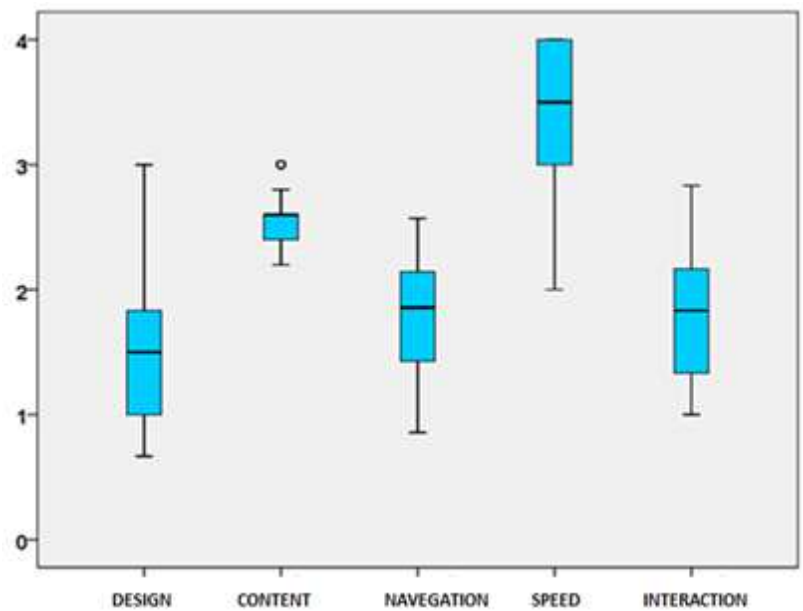

Figure 4. Extreme diagram and quartiles of Technical and Aesthetic Aspects

In Table 2 are presented the percentage rating of the Functional Aspects, the technical Aesthetic Aspects, and their criteria. The Functional Aspects offer a lower evaluation than Technical Aesthetical Aspects on the attribution of by Sufficient and Good, revealing the presence of a negative rating $(\mathrm{Bad}=28.1 \%)$.

On the Functional Aspect, the Accessibility is that explains higher percentage rating $(\mathrm{Bad}=56.1 \%)$. The update to that stands out in the classification with Good (19.3\%). The Update is the only criterion that presents a percentage, although reduced with the rating (Very Good $=3.5 \%$ ).

Relatively to the Technical Aesthetic Aspects, we stand out Speed of Access as that obtained the highest percentage of (Very Good $=$ $42.1 \%)$. Followed by the Content $(\operatorname{Good}=66.7 \%)$; have the Graphic Design and Multimedia Quality was the worst factor rating $(\mathrm{Bad}=49.1 \%)$ in approximately half of the websites.

Table 2. Percentage of the rating assigned to the functional aspects, the Technical and Aesthetic Aspects and their criteria

\begin{tabular}{|l|c|c|c|c|c|c|}
\hline & $\begin{array}{c}\text { Not } \\
\text { Applicable }\end{array}$ & Bad & Suffic. & Good & Very Good & TOTAL \\
\hline Functional aspects & $\%$ & $\%$ & $\%$ & $\%$ & $\%$ & $\%$ \\
\hline Technical aesthetics aspects & - & 28,1 & 70,2 & 1,8 & - & 100 \\
\hline Functional aspects & & & 91,1 & 8,9 & - & 100 \\
\hline Authority & 7,0 & 22,8 & 66,7 & 3,5 & - & 100 \\
\hline Update & - & 24,6 & 52,6 & 19,3 & 3,5 & 100 \\
\hline Usability & - & 28,1 & 61,4 & 10,5 & - & 100 \\
\hline Accessibility & 33,3 & 56,1 & 10,5 & - & - & 100 \\
\hline Communication & - & 22,8 & 64,9 & 12,3 & - & 100 \\
\hline Technical aesthetics aspects & & & & & & \\
\hline Graphic design and & 12,3 & 49,1 & 33,3 & 5,3 & - & 100 \\
\hline Multimedia quality & - & - & 33,3 & 66,7 & - & 100 \\
\hline Content & 1,8 & 26,3 & 66,7 & 5,3 & - & 100 \\
\hline Navigation & - & - & 17,5 & 40,4 & 42,1 & 100 \\
\hline Speed Access & - & 42,1 & 54,4 & 3,5 & - & 100 \\
\hline Interaction & & & & & \\
\hline
\end{tabular}


In Table 3 are represented the averages. It observed that the mean of the Aesthetic Technical Aspects was 2.21 greater than Functional Aspects which gained 1.75 standards. Table 3 show that the criteria that have stood out in the Functional Aspects were Usability (2.02), followed by the Update and Communication with 1.87 average. Technical Aesthetic Aspects the most outstanding criterion in this analysis was the Speed of Access to average 3.40, then Content with 2.56 and Navigation with average values of 1.81 . The criterion that most stand out, with higher average values it's the Usability and the lowest value is prominent the Accessibility.

\section{Table 3. Mean of the variables under study}

\begin{tabular}{|l|c|}
\hline & Mean \\
\hline Functional aspects & 1,75 \\
\hline Technical-aesthetics aspects & 2,21 \\
\hline Functional aspects & \\
\hline Authority & 1,78 \\
\hline Update & 1,97 \\
\hline Usabilityy & 2,02 \\
\hline Accessibility & 1,16 \\
\hline Communication & 1,81 \\
\hline Technical aesthetics aspects & 1,50 \\
\hline Graphic design and Multimedia quality & 2,56 \\
\hline Content & 1,81 \\
\hline Navigation & 3,40 \\
\hline Speed Access & 1,79 \\
\hline Interaction & \\
\hline
\end{tabular}

The Technical Aesthetic Aspects of the criterion that stands out are the test of Speed Access, with 3.40. That is, the Speed of Access to pages and Content didn't cause major obstacles, and the evaluator didn't can losses time in this criterion and obtained a Good result in the classification of Technical Aesthetic Aspects. The most part, of the evaluation criteria, obtained a Bad rating, between 1.16 and 1.97. Only the Usability, the Content, and Speed of Access achieved satisfactory results between 2.02 and 3.40 averages (Table 3 ).

Was used Mann-Whitney Test (Table 4) to check if there are significant differences between the teaching degrees match the websites regarding the variables under study. The results presented in Table 4 indicate that there are statistically significant differences whose evaluations are superior on the websites of the High School, particularly in the Functional Aspects $(\mathrm{p}=0.004)$ ); on Authority ( $\mathrm{p}=0.047)$; in Update $(\mathrm{p}=0.013)$, on Communication $(p=0.007)$ and Interaction $(p=0.021)$.
Table 4. Mean and standard deviation of the variables under study and $p$-value by level of education

\begin{tabular}{|c|c|c|c|c|c|}
\hline & \multicolumn{2}{|c|}{$\begin{array}{c}\text { Primary School } \\
(n=20)\end{array}$} & \multicolumn{2}{|c|}{$\begin{array}{l}\text { High School } \\
(n=37)\end{array}$} & \multirow[b]{2}{*}{ p.Mann-Whimey } \\
\hline & Mean & dp & Mean & dp & \\
\hline Functional aspects & 1,57 & .25 & 1,84 & .34 & ,004 \\
\hline Technical-aesthetics aspects & 2,18 & .19 & 2,23 & .25 & 349 \\
\hline \multicolumn{6}{|l|}{ Functional aspects } \\
\hline Authority & 1,61 & .57 & 1,87 & .35 & .047 \\
\hline Update & 1,68 & .44 & 2,13 & .72 &, 013 \\
\hline Ussbility & 1.88 & .48 & 2.10 & .55 & .134 \\
\hline Accessibility & 1,15 & 36 & 1,18 & .37 & .717 \\
\hline Communication & 1.55 & .38 & 1.95 & .59 &, 007 \\
\hline \multicolumn{6}{|l|}{ Technical-aesthetics aspects } \\
\hline $\begin{array}{l}\text { Graphic design and Multimedia } \\
\text { quality }\end{array}$ & 1.57 & .47 & 1.46 & .55 & .308 \\
\hline Content & 2,55 & .16 & 2,57 & .25 & .796 \\
\hline Navigation & 1,80 & .38 & 1,82 & .46 & .724 \\
\hline Speed of access & 3,40 & .62 & 3,41 & .60 & 986 \\
\hline Interaction & 1.58 & .48 & 1.91 & .53 & ,021 \\
\hline
\end{tabular}

\section{DISCUSSION OF RESULTS}

Analyzing the differences in categorical assessment attributed to Functional Aspects and Technical Aesthetic Aspects (Table 2) by the degree of knowledge of websites (Table 4), allows us to observe that both aspects present a satisfactory assessment in secondary school sites. That's, Functional aspects, the educational websites of the Primary School obtained values in a greater number of Sufficient (classification of two (2)).

Concerning Authority, the educational websites of High School got the highest number of sites with Bad rating (didn't accomplish the requirement established by us) in connection with the Primary School websites. Unlike the recoverability of Sufficient attributed more to High School sites. To the development of Good, both of criteria obtained the same number of places with this classification.

With Update, the High School educational websites have received the largest number of locations with Bad (didn't accomplish the requirement established by us) in connection with the sites of the Primary School. Unlike the recoverability of Sufficient attributed more to of High School websites. About the valorization of Good, this discretion was the High School sites that have obtained the largest number of places with this classification. In this criterion, we observed with excellent (Very Good) rating was High School websites. This means that accomplished the requirements of the Update Date of the place and had no old and misleading links.

In Usability criteria, the educational websites of High School obtained the highest number of sites with Sufficient to the websites of Primary School. About to the valorization of Good, this discretion was the High School websites that have obtained the largest number of sites with this classification.

In connection with educational websites of the Primary and High School the Accessibility, received a Bad rating (didn't accomplish the requirement established by us), both with a large number of sites. Unlike the recoverability of sufficient valorization the number below this rank, while the High School websites stand out. In this criterion were many High Schools sites (number). Primary School, in which three indicators of this approach doesn't apply, then you can't enhance the images, image maps, sounds, 
and videos without alternative text, as well as the absence of sound, and videos without the user could control.

In communication, the High School educational websites have obtained the largest number of sites with Bad (didn't accomplish the requirement established by us) in connection with the sites of the Primary School. Unlike the recoverability of sufficient attributed more to High School sites. To the evaluation of Good in this criterion, were High School websites that have obtained good quality results.

Analyze the criteria Technical Aesthetic Aspects show that the educational sites that have received a better classification of sufficient remain the places related to Secondary Education.

To the Graphic Design and Multimedia Quality, the educational sites of High School obtained the highest number of locations with Bad (didn't accomplish the requirement established) concerning the places of the Primary School. Unlike the recoverability of sufficient attributed more to the High School websites. With a qualitative appreciation of Good, were just Secondary sites who have obtained this ranking, unlike websites of the Primary School, didn't gain this qualification.

To Content the educational sites of High School got the highest number of websites with Good and sufficient, about primary internet sites.

In navigation, the High School educational websites have gained the largest number of sites with adequate to the Primary Internet sites. The classification of Good, this discretion was the High School websites that have obtained the most significant number of places with this classification. The Bad purchased in greater numbers by High School. Also, existed only in the teaching degree websites in the proper speed indicator in the animations and reading the data, but it hasn't been possible to assess because it didn't exist in some websites.

The criteria Speed of Access in both qualitative valuations obtained Education degrees between Sufficient, Good, and Very Good. This criterion didn't have a negative score and the level of education that most stood out was his High School.

In Interaction the educational websites of High School obtained the highest number of websites (although, more or less equated) with Bad (didn't accomplish the requirement established by us) in connection with the sites of the Primary School. Unlike the recoverability of sufficient attributed more to High School websites. The valuation of Good in this criterion was in the High School the only websites that have obtained good quality results.

We note that the criteria got best results were those relating to High School Education. This result may arise due to the intended audience be more demanding that the resources directed to the Primary School. We note that the criteria evaluated within the two aspects, the High School websites are the most demanding that stand out, only in some indicators don't apply to recovery of images, sounds, videos. That's users of High Education as well as the creators or authors of these resources, intended the contents are more conscientious than in this degree, High School (preparing for the University entrance) require more care resources, with greater interaction between users and with varying content and more up to date. Perhaps, the high degree of education demands it. Unlike the resources directed to the Primary School in which the creators' and authors' consider, for example, that media funds are more suitable for this level of education.

\section{CONCLUSION}

In this type of online resources, as Aedo and Landoni [1] speak the local teacher plays more than one role at the same time, is facing difficulties, in particular, is having second thoughts about whether the content is appropriate for the intended audience. One way to overcome this constraint may be strict compliance with applicable steps. One of them, the beginning of development is still important, heuristic evaluation. This phase will be fundamental for the actual realization of the work.

However, at a time when higher education institutions are investing in education and research and the Web, it's essential that teachers' and educational authors' are sensitive to these realities and bother to create conditions for this kind of work to invest in e-content. We believe e-Content deliberately designed promote the educational work and are an asset to students.

Analyzed the results using SPSS statistical software educational web sites with higher ranking were the Secondary Education. The internet site with the name Matematica.absolutamente (URL: http://mat.absolutamente.net/) achieved better scores in both the Functional Aspects as the Technical-aesthetic. The following was the website with the name geometria descritiva (URL: http://www.gd.elisiosilva.com/); atractor.matemática interactiva (URL: http://www.atractor.pt/) achieved a third place. The educational website for Primary School that has positioned better was the site named davidcosta (URL: http://www.davcosta.com/). All the sites as mentioned above qualitative values obtained with sufficient rating.

To conclude, in fifty-seven educational locations in this study twenty-five earned a qualitative classification Sufficient. Six of the twenty-five educational websites belonged to the Primary School, and nineteen encompassed in High School. The remaining websites obtained qualitative values in $\mathrm{Bad}$ rating.

In summary, the results of this paper allow us to conclude that there is a lot to learn about how to develop, (not only for teachers but also for institutions for the sharing and dissemination of teaching materials) which the criteria and requirements to value when you create online educational resources. There is a long way to go to achieve satisfactory results in evaluating the quality of Websites.

\section{ACKNOWLEDGMENTS}

This paper is a possible perspective for a doctoral research entitled: [websites of learning support in Primary and High School in Portugal: a performance and usability study] held at the University of Salamanca linked to the Ph.D. Knowledge Society Programme. My thanks to the directors of the thesis, Jose Antonio Cordón García, and Raquel Gómez Díaz. 


\section{REFERENCES}

[1] Aedo, I. and Landoni, M. 2003. Digital contents for education. Educational Technology \& Society, 6 (4), 6-7. Access from http://ifets.ieee.org/periodical/6_a/2.pdf.

[2] Alves, F. and Quiroa Herrera, M. L. 2007. Análisis y evaluación de sitios web de bibliotecas nacionales: los casos de Brasil y de Portugal. Revista Española de Documentación Científica, 30 (2), 199-217. Access from http://redc.revistas.csic.es/index.php/redc/article/view/379/39 $\underline{1}$

[3] Area Moreira, M. 2003. De los webs educativos al material didáctico web. Comunicación y pedagogía de nuevas tecnologías y recursos didácticos, 188, 32-37. Access from http://manarea.webs.ull.es/articulos/art17_sitiosweb.pdf

[4] Carvalho, A. A., Simões, A., and Silva, J. P. 2005. Indicadores de qualidade e de confiança de um site. In M. P. Alves \& E. A. Machado (org.), Avaliar as aprendizagens: Actas das Jornadas ADMEE (Braga) CIED, 17-28. Access from

http://repositorium.sdum.uminho.pt/bitstream/1822/7774/1/0 5AnaAmelia.pdf

[5] Carvalho, A. A. A. 2006. Indicadores de qualidade de sites educativos. Cadernos SACAUSEF - Sistema de avaliação, Certificação e Apoio à Utilização de Software para a Educação e a formação, 2, 55-78. Access from https://repositorium.sdum.uminho.pt/bitstream/1822/5922/1/ Indicadores\%20de\%20Qualidade\%20de\%20Sites\%20SACAUSEF\%20-AAC.pdf

[6] Codina, L. 2006. Metodología de análisis y evaluación de recursos digitales en línea. Barcelona: UPF. Access from http://www.digidocweb.net/metodos.htm.

[7] Hinrichs, U. and Carpendale, S. 2011. Gestures in the wild: studying multi-touch gesture sequences on interactive tabletop exhibits. Annual Conference on Human factors in computing systems (CHI'11), (2011), 3023-3032. Access from http://dl.acm.org/citation.cfm?id=1979391

[8] Jiménez Piano, M., and Ortiz-Repiso Jiménez, V. 2007. Evaluación y calidad de sedes web. Giijón, Ediciones Trea. ISBN 978-84-9704-318-2.

[9] Lopéz Carreño, R. 2007. Los portales educativos: clasificación y componentes. Anales de documentación, 10, 233-244. Access from http://revistas.um.es/analesdoc/article/view/1171/1221

[10] Maroco, J. 2014. Análise estatística: Com o SPSS Statistics. $6^{a}$ ed. Lisboa: Report Number. ISBN 978-989-96763-4-3.

[11] Marquès Graells., P. 2000. Los sitios web de interés educativo: clasificación, evaluación y exploración didáctica. Access from http://dewey.uab.es/pmarques.

[12] Nielson, J. 2004. Designing web usability. Munich, Marttecnik Verlag.

[13] Olsina, L., Godoy, D., Lafuente, G. J., and Rossi, G. 2008. Specifying quality characteristics and attributes for websites. In Web Engineering: managing diversity \& complexity of web application development. Heidelberg, Springer, 266$278 . \quad$ Access from http://link.springer.com/chapter/10.1007\%2F3-540-45144$\underline{726}$.
[14] Pinto Molina, M., and Gómez-Camareiro, C. 2011. Propuestas de criterios e indicadores internacionales para la evaluación de los recursos educativos electrónicos. Ibersid, 5, 81-87. Access from http://www.ibersid.eu/ojs/index.php/ibersid/article/view/393 $\underline{5}$.

[15] Pinto Molina, M. 2008. Evaluación de la calidad de recursos electrónicos educativos para el aprendizaje significativo. Cadernos SACAUSEF, 2, 25-43. Access from http://docplayer.es/15797506-Evaluacion-de-la-calida-derecursos-electronicos-educativos-para-el-aprendizajesignificativo.html.

[16] Santos, A. M. 2015. Theoretical-Methodological proposal to evaluate the quality of educational websites to support education. In TEEM '15: Proceedings of the 3rd International Conference on Technological Ecosystems for Enhancing Multiculturality, (Porto, Portugal, 07-09 Oct. 2015). ACM, New York, NY, 397-401). DOI: http://dx.doi.org/10.1145/2808580.2808640. ACM 978-14503-3442-6/15/10.

[17] Vosylius, A. E. and Lapin, K.. 2015. Usability of Educational Websites for Tablet Computers. In MIDI 2015: Proceedings of the Mulitimedia, Interaction, Design and Innnovation Proceedings of the Mulitimedia, Interaction, Design and Innnovation, (Warsaw, Poland, 29-30 Jun. 2015). ACM, New York, NY. DOI: http://dx.doi.org/10.1145/2814464.2814467.

1 University of Salamanca, Documentation Faculty, Francisco Vitoria 6-16,37008bSalamanca (Spain) +34923294580, anamariasantos@usal.es 
ANNEX 1. Web sites in Study

http://www.prof2000.pt/users/aabrantes/

http://omeubau.net/

http://pedronoia.net/

http://arturrosa81.no.sapo.pt/

http://www.prof2000.pt/users/roliveira0/

http://profs.ccems.pt/RosaFerreira/

http://mat.absolutamente.net/

http://www.xkmat.pt.to/

http://www.prof2000.pt/users/lpa/

http://zepaulo.planetaclix.pt/

http://www.prof2000.pt/users/luar/e12/

http://www.prof2000.pt/users/lebre/af/

http://www.prof2000.pt/users/ferralopes/

http://www.gd.elisiosilva.com/

http://www.atractor.pt/

http://eduvisilva.com.sapo.pt/

https://sites.google.com/site/amsfrancisco/home

http://elektron.no.sapo.pt/

http://sdig.home.sapo.pt/index.html

http://dteedmi.no.sapo.pt/

http://www.josematias.pt/

https://sites.google.com/site/luisalegrio/

https://sites.google.com/site/ruicancelinha/automacao

http://www.prof2000.pt/users/dicsoc/

http://www.prof2000.pt/users/anaroda/pfrances/index.htm

http://www.electronica-pt.com/

http://nautilus.fis.uc.pt/molecularium/

http://www.laboratorio.online.pt

http://faroldasletras.no.sapo.pt

http://esjmlima.prof2000.pt/figuras_estilo/figuras_estilo.html http://serreta-creminer.fc.ul.pt/

http://quimica12mp.no.sapo.pt/index.html

http://curlygirl.no.sapo.pt/home.htm

http://josefleal.no.sapo.pt/index.html

http://afilosofia.no.sapo.pt/

http://www.prof2000.pt/users/fasp.esds1/

http://criticanarede.com/index.html

http://www.mat.uc.pt/ mat1042/mat10/

http://www.fq.ciberprof.com/

http://aprenderbrincando.no.sapo.pt/

http://www.coolkids.guarda.pt/

http://www.davcosta.com/

http://nonio.eses.pt/fabulas/

http://fichasprimeirociclo.no.sapo.pt/

http://www.cercifaf.org.pt/mosaico.edu/index.htm

http://www.nossoamiguinho.pt/

http://www.prof2000.pt/users/jsaraiva/

http://www.prof2000.pt/users/jotave/fichas/

http://www.prof2000.pt/users/rosaritos/testes/index.htm

http://quadradomagico.no.sapo.pt/

http://www.quadroegiz.com/p_2.htm

http://recreio.no.sapo.pt/main.htm

http://recursoseducativos.no.sapo.pt/

http://susanajesus.no.sapo.pt/

http://zonix.no.sapo.pt/

http://jogosinfantis.no.sapo.pt/

http://www.prof2000.pt/users/img/Matematica.htm

http://www.ese.ips.pt/abolina/optimista/index.html

http://arquivo.ese.ips.pt/abolina/index.html

http://decalhetaforma.wix.com/recursoseducativos 